\title{
Pengaruh Produk Domestik Regional Bruto, Pengangguran dan Indeks Pembangunan Manusia terhadap Kemiskinan di Jawa Barat dengan Menggunakan Analisis Data Panel
}

\author{
Sussy Susanti \\ STIE Ekuitas \\ Jl. P.H.H. Mustofa No. 31 Bandung 40124 \\ Email: sussy.rebab19@gmail.com
}

\begin{abstract}
ABSTRAK
Kemiskinan merupakan persoalan kompleks yang masih sulit terpecahkan hampir di setiap daerah di Indonesia, selain itu kemiskinanpun merupakan salah satu tolok ukur kondisi sosial ekonomi dalam menilai keberhasilan pembangunan yang dilakukan pemerintah di suatu daerah. Banyak sekali masalah sosial yang bersifat negatif timbul akibat meningkatnya kemiskinan. Jawa Barat merupakan provinsi yang tingkat kemiskinannya masih relatif tinggi dengan tingkat pengangguran yang semakin meningkat dari tahun ke tahun. Tingkat kemiskinan ini dapat dipengaruhi oleh beberapa faktor diantaranya PDRB (Produk Domestik Regional Bruto, IPM (Indeks Pembangunan Manusia) dan pengangguran. Selain faktor-faktor tersebut, masalah kemiskinan tidak bisa terlepas dari masalah waktu (periode) sehingga analisis kemiskinan ini memerlukan pendekatan analisis yang tidak hanya mempertimbangkan data cross section namun juga menggunakan data time series. Analisis yang tepat untuk permasalahan ini adalah analisis data panel. Studi ini meneliti tentang pengaruh PDRB, IPM dan pengangguran terhadap kemiskinan di Provinsi Jawa Barat, dalam hal ini untuk seluruh kabupaten/kota di Jawa Barat tahun 2009-2011. Tujuan penelitian ini diharapkan dapat menganalisis bagaimana dan seberapa besar PDRB, IPM dan pengangguran berpengaruh terhadap kemiskinan di Provinsi Jawa Barat, sehingga nantinya diharapkan dapat digunakan sebagai salah satu dasar dalam penentuan kebijakan dalam mengatasi kemiskinan di Jawa Barat. Data yang digunakan dalam penelitian ini adalah data sekunder yang diperoleh dari Badan Pusat Statistik (BPS). Sedangkan metode analisis yang digunakan dalam penelitian ini adalah metode analisis regresi linier panel data dengan bantuan STATA 9. Hasil penelitian menunjukkan bahwa PDRB, Pengangguran dan IPM berpengaruh signifikan terhadap tingkat kemiskinan di Jawa Barat pada tahun 2009-2011.
\end{abstract}

Kata Kunci: Data panel, efek tetap, efek random, kemiskinan

\begin{abstract}
Poverty is a complex issue that is difficult to solve in almost every region in Indonesia. Poverty is socio-economic measurement in assessing the success of the government's development. There are so many negative social problems that are arising due to increasing poverty rate. Poverty rates in West Java are still relatively high consistent with increasing unemployment from year to year. The poverty rate can be influenced by several factors such as GDP, HDI and unemployment. In addition to these factors, the problem of poverty cannot be separated from issues of the time (period)
\end{abstract}


so that the poverty analysis requires analytical approaches that not only consider the cross section data but also using time series data. Proper analysis for this problem is the panel data analysis. This study examines the influence of GDP, HDI, unemployment and poverty in the province of West Java, in this case for all districts/cities in West Java in 2009-2011. The purpose of this study is expected to analyze how and how much GDP, HDI, and unemployment affect poverty in the province of West Java, thus expected to be used as a basis in determining policy in addressing poverty in West Java. The data used in this study is a secondary data obtained from the Central Statistics Agency (BPS). The methods of analysis used in this study is linear regression analysis for panel using STATA 9. The results showed that GDP, Unemployment and HDI levels significantly affect poverty level in West Java in 2009-2011.

Keyword: panel data, fixed effect, random effect, poverty

\section{Pendahuluan}

Kemiskinan merupakan persoalan kompleks yang masih sulit terpecahkan hampir di setiap daerah di Indonesia. Kebijakan-kebijakan pemerintah untuk mengatasi kemiskinan masih terus menerus dikaji sampai saat ini. Jawa Barat merupakan salah satu propinsi yang tingkat kemiskinannya masih cukup tinggi sehingga perlu diketahui faktor apa yang mendasarinya dan seberapa besar pengaruh faktor tersebut sehingga bisa dicari solusi untuk menurunkan tingkat kemiskinan tersebut.

Menurut World Bank (2004) dalam Whisnu Adhi Saputra (2011), salah satu sebab kemiskinan adalah karena kurangnya pendapatan dan aset (lack of income and assets) untuk memenuhi kebutuhan dasar seperti makanan, pakaian, perumahan dan tingkat kesehatan dan pendidikan yang dapat diterima (acceptable). Selain itu kemiskinan juga berkaitan dengan keterbatasan lapangan pekerjaan dan biasanya mereka yang dikategorikan miskin (the poor) tidak memiliki pekerjaan (pengangguran), serta tingkat pendidikan dan kesehatan mereka pada umumnya tidak memadai. Mengatasi masalah kemiskinan tidak dapat dilakukan secara terpisah dari masalah-masalah pengangguran, pendidikan, kesehatan dan masalahmasalah lain yang secara eksplisit berkaitan erat dengan masalah kemiskinan. Dengan kata lain, pendekatannya harus dilakukan lintas sektor, lintas pelaku secara terpadu dan terkoordinasi dan terintegrasi. (www.bappenas.go.id).

Analisis untuk mengetahui keterkaitan antara kemiskinan dengan faktorfaktor lain ini harus juga mempertimbangkan perubahan dari waktu ke waktu yang tidak bisa diselesaikan dengan analisis statistik biasa. Analisis statistik konvensional (analisis regresi, analisis trend sekuler) mensyaratkan penggunaan data hanya untuk data cross section atau data time series saja. Sedangkan banyak sekali studi atau penelitian dilakukan terhadap fenomenafenomena yang tidak tunggal yang diamati dalam beberapa periode atau 
tempat secara sekaligus. Analisis yang terpisah untuk data cross section atau time series saja akan menyediakan kesimpulan yang bisa jadi salah atau tidak logis atau tidak sesuai dengan teori yang mendasarinya.

Untuk mengatasi permasalahan tersebut, analisis data yang dibutuhkan harus bersifat multidimensi yaitu dimensi cross section dan dimensi time series. Struktur data yang memasukkan dimensi cross section (individual) dan time series disebut data panel. Dengan struktur dua dimensi ini memungkinkan peneliti untuk mengamati perubahan dinamis karakteristik suatu individu/observasi dari waktu ke waktu.

Kemiskinan merupakan salah satu tolak ukur kondisi sosial ekonomi dalam menilai keberhasilan pembangunan yang dilakukan pemerintah di suatu daerah. Banyak sekali masalah-masalah sosial yang bersifat negatif timbul akibat meningkatnya kemiskinan. Menurut World Bank dalam situsnya http://web.worldbank.org menyatakan bahwa sejak pemilu nasional tahun 2004, persentase masyarakat miskin telah turun dari 16.7 persen menjadi 14.15 persen (2009).

Berdasarkan data dari Badan Pusat Statistik (BPS), pada tahun 2012, tercatat masih terdapat sebanyak 4.3 juta penduduk miskin di Jawa Barat. Angka itu sekitar 10,09 persen dari total penduduk Jawa Barat yang mencapai 45 juta jiwa. Sejak tahun 2008-2012, penurunan angka kemiskinan di Jawa Barat terbilang kecil. Tahun 2008, persentase kemiskinan berada di angka 13,01 persen, tahun 2009 menjadi 11,96 persen, 2010 menjadi 11,27 persen, kemudian tahun 2011 turun menjadi 10,65 persen, dan tahun 2012 menjadi 10,09 persen. Dengan kata lain, dari 2008 hingga 2012 persentase penurunan hanya 2,92 persen. Angka itu jauh di bawah provinsi lain. Jawa Barat, sejak 2008-2012 persentase penurunan angka kemiskinannya mencapai 3,89 persen, Lampung 4,80 persen, dan Jawa Timur 5,11 persen (http://www.klikgalamedia.com/kemiskinan-di-jabar-tinggi). Untuk itu diperlukan penelitian lebih lanjut mengenai faktor-faktor yang dapat berpengaruh terhadap tingkat kemiskinan di seluruh kabupaten/kota agar dapat diketahui faktor-faktor yang perlu dipacu untuk mengatasi masalah kemiskinan. Besarnya angka kemiskinan dapat dipengaruhi oleh berbagai faktor terutama Produk Domestik Regional Bruto (PDRB), indeks pembangunan manusia, dan pengangguran.

Dalam makalah ini fokus utama permasalahan adalah bagaimana pengaruh PDRB, IPM, dan pengangguran terhadap kemiskinan di Jawa Barat pada tahun 2009-2011.

\section{Tinjauan Pustaka}

Kemiskinan menurut World Bank didefinisikan sebagai The denial of choice and opportunities most basic for human development to lead a long healthy, creative life and enjoy a decent standard of living freedom, self 
esteem and the respect of other.

Kemiskinan (poverty) merupakan masalah yang dihadapi oleh seluruh negara, terutama di negara berkembang seperti Indonesia. Hal ini dikarenakan kemiskinan itu bersifat multidimensional artinya karena kebutuhan manusia itu bermacam-macam, maka kemiskinan pun memiliki banyak aspek primer yang berupa miskin akan aset, organisasi sosial politik, pengetahuan, dan keterampilan serta aspek sekunder yang berupa miskin akan jaringan sosial, sumber-sumber keuangan, dan informasi. Dimensidimensi kemiskinan tersebut termanifestasikan dalam bentuk kekurangan gizi, air, perumahan yang sehat, perawatan kesehatan yang kurang baik, dan tingkat pendidikan yang rendah. Selain itu, dimensi-dimensi kemiskinan saling berkaitan baik secara langsung maupun tidak langsung. Hal ini berarti kemajuan atau kemunduran pada salah satu aspek dapat mempengaruhi kemajuan atau kemunduran aspek lainnya. Dan aspek lain dari kemiskinan ini adalah bahwa yang miskin itu manusianya baik secara individual maupun kolektif [16].

\section{Ukuran Kemiskinan}

Garis kemiskinan adalah suatu ukuran yang menyatakan besarnya pengeluaran untuk memenuhi kebutuhan dasar minimum makanan dan kebutuhan non-makanan atau standar yang menyatakan batas seseorang dikatakan miskin bila dipandang dari sudut konsumsi. Garis kemiskinan yang digunakan setiap negara berbeda-beda, sehingga tidak ada satu garis kemiskinan yang berlaku umum. Hal ini disebabkan karena adanya perbedaan lokasi dan standar kebutuhan hidup.

Menurut BPS (2010), penetapan perhitungan garis kemiskinan dalam masyarakat adalah masyarakat yang berpenghasilan di bawah Rp.7.057 per orang per hari. Penetapan angka Rp.7.057 per orang per hari tersebut berasal dari perhitungan garis kemiskinan yang mencakup kebutuhan makanan dan non makanan. Untuk kebutuhan minimum makanan digunakan patokan 2.100 kilo kalori per kapita per hari. Sedang untuk pengeluaran kebutuhan minimum bukan makanan meliputi pengeluaran untuk perumahan, pendidikan, dan kesehatan.

Sedangkan ukuran menurut World Bank menetapkan standar kemiskinan berdasarkan pendapatan per kapita. Penduduk yang pendapatan per kapitanya kurang dari sepertiga rata-rata pendapatan perkapita nasional. Dalam konteks tersebut maka ukuran kemiskinan menurut World Bank adalah USD $\$ 2$ per orang per hari.

\section{Produk Domestik Regional Bruto}

PDRB menurut BPS didefinisikan sebagai jumlah nilai tambah yang dihasilkan oleh seluruh unit usaha dalam suatu wilayah, atau merupakan jumlah seluruh nilai barang dan jasa akhir yang dihasilkan oleh seluruh 
unit ekonomi di suatu wilayah. PDRB atas dasar harga berlaku menggambarkan nilai tambah barang dan jasa yang dihitung menggunakan harga pada setiap tahun, sedang PDRB atas dasar harga konstan menunjukkan nilai tambah barang dan jasa yang dihitung menggunakan harga pada tahun tertentu sebagai dasar dimana dalam perhitungan ini digunakan tahun 2000. PDRB atas dasar harga konstan digunakan untuk mengetahui pertumbuhan ekonomi dari tahun ke tahun [17], sedangkan menurut BPS PDRB atas dasar harga berlaku digunakan untuk menunjukkan besarnya struktur perekonomian dan peranan sektor ekonomi.

Kuncoro (2001) menyatakan bahwa pendekatan pembangunan tradisional lebih dimaknai sebagai pembangunan yang lebih memfokuskan pada peningkatan PDRB suatu provinsi, kabupaten, atau kota. Sedangkan pertumbuhan ekonomi dapat dilihat dari pertumbuhan angka PDRB. Saat ini umumnya PDRB baru dihitung berdasarkan dua pendekatan, yaitu dari sisi sektoral/lapangan usaha dan dari sisi penggunaan. Selanjutnya PDRB juga dihitung berdasarkan harga berlaku dan harga konstan. Total PDRB menunjukkan jumlah seluruh nilai tambah yang dihasilkan oleh penduduk dalam periode tertentu.

\section{Indeks Pembangunan Manusia}

Indikator pembangunan manusia merupakan salah satu alat ukur yang dapat digunakan untuk menilai kualitas pembangunan manusia, baik dari sisi dampaknya terhadap kondisi fisik manusia (kesehatan dan kesejahteraan) maupun yang bersifat non-fisik (intelektualitas). Pembangunan yang berdampak pada kondisi fisik masyarakat tercermin dalam angka harapan hidup serta kemampuan daya beli, sedangkan dampak non-fisik dilihat dari kualitas pendidikan masyarakat.

Indeks pembangunan manusia (IPM) merupakan indikator strategis yang banyak digunakan untuk melihat upaya dan kinerja program pembangunan secara menyeluruh di suatu wilayah. Dalam hal ini IPM dianggap sebagai gambaran dari hasil program pembangunan yang telah dilakukan beberapa tahun sebelumnya. Demikian juga kemajuan program pembangunan dalam suatu periode dapat diukur dan ditunjukkan oleh besaran IPM pada awal dan akhir periode tersebut. IPM merupakan ukuran untuk melihat dampak kinerja pembangunan wilayah yang mempunyai dimensi yang sangat luas, karena memperlihatkan kualitas penduduk suatu wilayah dalam hal harapan hidup, intelelektualitas dan standar hidup layak.

Pada pelaksanaan perencanaan pembangunan, IPM juga berfungsi dalam memberikan tuntunan dalam menentukan prioritas perumusan kebijakan dan penentuan program pembangunan. Hal ini juga merupakan tuntunan dalam mengalokasikan anggaran yang sesuai dengan kebijakan umum yang telah ditentukan oleh pembuat kebijakan dan pengambil keputusan. IPM merupakan indeks komposit yang dihitung sebagai rata-rata 
sederhana dari tiga indeks yang menggambarkan kemampuan dasar manusia dalam memperluas pilihan-pilihan, yaitu: Indeks Harapan Hidup, Indeks Pendidikan, Indeks Standar Hidup Layak

Rumus umum yang dipakai adalah sebagai berikut:

dengan

$$
\mathrm{IPM}=1 / 3(\mathrm{X} 1+\mathrm{X} 2+\mathrm{X} 3)
$$

$$
\begin{aligned}
& \mathrm{X} 1=\text { Indeks Harapan Hidup } \\
& \mathrm{X} 2=\text { Indeks Pendidikan } \\
& \mathrm{X} 3=\text { Indeks Standar Hidup Layak }
\end{aligned}
$$

\section{Pengangguran}

Dalam standar pengertian yang sudah ditentukan secara internasional, yang dimaksudkan dengan pengangguran adalah seseorang yang sudah digolongkan dalam angkatan kerja yang secara aktif sedang mencari pekerjaan pada suatu tingkat upah tertentu, tetapi tidak dapat memperoleh pekerjaan yang diinginkannya. Oleh sebab itu, menurut [16] pengangguran biasanya dibedakan atas tiga jenis berdasarkan keadaan yang menyebabkannya, antara lain:

1. Pengangguran friksional, yaitu pengangguran yang disebabkan oleh tindakan seseorang pekerja untuk meninggalkan kerjanya dan mencari kerja yang lebih baik atau sesuai dengan keinginannya.

2. Pengangguran struktural, yaitu pengangguran yang disebabkan oleh adanya perubahan struktur dalam perekonomian.

3. Pengangguran konjungtur, yaitu pengangguran yang disebabkan oleh kelebihan pengangguran alamiah dan berlaku sebagai akibat pengurangan dalam permintaan agregat.

Sedangkan bentuk-bentuk pengangguran adalah:

1. Pengangguran terbuka (open unemployment), adalah mereka yang mampu dan seringkali sangat ingin bekerja tetapi tidak tersedia pekerjaan yang cocok untuk mereka.

2. Setengah pengangguran (under unemployment), adalah mereka yang secara nominal bekerja penuh namun produktivitasnya rendah sehingga pengurangan dalam jam kerjanya tidak mempunyai arti atas produksi secara keseluruhan.

3. Tenaga kerja yang lemah (impaired) adalah mereka yang mungkin bekerja penuh tetapi intensitasnya lemah karena kurang gizi atau penyakitan.

4. Tenaga kerja yang tidak produktif, adalah mereka yang mampu bekerja secara produktif tetapi tidak bisa menghasilkan sesuatu yang baik.

\section{Pengertian Data Panel}

Data panel mengacu pada himpunan data yang bersifat multidimensi. Multidimensi disini diartikan sebagai data yang mengandung observasi dimana fenomena/gejala yang diukur (observed) lebih dari satu dan waktu 
pengumpulan data yang lebih dari satu periode untuk satu individu (orang, perusahaan, wilayah, negara, dan lain-lain) yang sama.

Penggunaan data panel tidak terlepas dari kelebihan dan kekurangannya. Terdapat beberapa keunggulan dari penggunaan data panel dibandingkan dengan data time series dan cross section. Menurut [11] keunggulan penggunaan panel data adalah :

1. Dapat memberikan peneliti jumlah pengamatan besar, meningkatkan degree of freedom (derajat kebebasan), data memiliki variabilitas yang besar dan mengurangi kolinearitas antara variabel penjelas, di mana dapat menghasilkan estimasi ekonometri yang efisien.

2. Data panel memberikan informasi lebih banyak yang tidak dapat diberikan hanya oleh data cross section dan time series saja.

3. Data panel akan memberikan penyelesaian yang lebih baik dalam inferensi perubahan dinamis dibandingkan dengan data cross section.

Sementara itu [10] mengatakan bahwa terdapat beberapa keuntungan dari penggunaan model panel, seperti :

1. Mengingat penggunaan data panel juga meliputi data cross section dalam rentang waktu tertentu, maka data akan rentan dari

heterogenitas. Penggunaan teknik dan estimasi data panel akan memperhitungkan secara eksplisit heterogenitas tersebut.

2. Dengan pengkombinasian, data akan memberikan informasi yang lebih, tingkat kolinearitas yang lebih kecil antar variabel dan lebih efisien.

3. Penggunaaan data panel, mampu meminimasi bias yang dihasilkan jika kita mengagregasikan data individu ke dalam agregasi yang luas.

4. Keuntungan lain dari penggunaan data panel adalah penyatuan informasi dari data cross section dan time series yang akan mengurangi permasalahan yang timbul akibat hilangnya variabel (omitted variables). Dalam data panel, hilangnya suatu variabel akan tetap menggambarkan perubahan lainnya akibat penggunaan data time series. Selain itu penggunaan data yang tidak lengkap (unbalanced data) tidak akan mengurangi ketajaman estimasi karena penggunaan dummy dalam metode Least square Dummy Variable (LSDV) akan mengatasi data yang berantakan tersebut (Gujarati, 2004).

\section{Model-model Panel Data}

Model data panel memeriksa pengaruh kelompok, pengaruh waktu, atau keduanya untuk mengatasi pengaruh heterogen atau individu yang mungkin teramati atau tidak teramati. Pengaruh-pengaruh adalah pengaruh tetap atau pengaruh random. Fixed effect model memeriksa jika intercep bervariasi antar kelompok atau waktu, sementara itu random effect model menggali perbedaan pada komponen varians error (error component variance) antar individu atau antar waktu. One-way model terdiri atas hanya satu himpunan variabel boneka (dummy) (misal: perusahaan 1, perusahaan 2,...) sedangkan twoway model mempertimbangkan dua himpunan variabel dummy (misal: kota 1 , kota 2 , dan tahun 1 , tahun $2, \ldots$ ). 


\section{Pooled OLS}

Jika pengaruh individu $u_{i}=$ (pengaruh spesifik cross-sectional atau waktu) tidak ada $\left(u_{i}=0\right)$, ordinary least squares (OLS) menghasilkan taksiran parameter yang efisien dan konsisten untuk model regresi di bawah ini

$$
\begin{aligned}
& y_{i t}=a+X_{i t} \beta+\varepsilon_{i t} \\
& \mathrm{Y}=\text { Variabel Dependen } \\
& \mathrm{X}=\text { Variabel Independen } \\
& \mathrm{a}=\text { Intersep }=\text { Kontanta }=\text { individual effect } \\
& B=\text { slope }=\text { parameter yang diestimasi } \\
& \mathrm{i}=\text { Urutan } \\
& \text { individu } \\
& \mathrm{t}=\text { Periode Waktu } \\
& \varepsilon=\text { Variabel Gangguan (disturbance term) }
\end{aligned}
$$

OLS terdiri dari 5 asumsi inti $[8,13]$ :

1. Linieritas: variabel dependen dirumuskan sebagai fungsi linier dari sekumpulan vaiabel independen dan faktor kekekeliruan (error/disturbance term)

2. Eksogenitas: bahwa nilai ekpektasi dari error adalah nol yang berarti faktor pengganggu tidak berkorelasi dengan regresor manapun.

3. Faktor pengganggu mempunyai varians yang sama (homoskedasticity) dan tidak berkorelasi satu sama lainnya (nonautocorrelation)

4. Pengamatan pada variabel independen bersifat tetap pada pengukuran yang berulang tanpa kesalahan pengukuran.

5. No Multicolinearity: bahwa tidak ada hubungan linier antar variabel independen.

\section{Fixed versus Random Effects}

Data panel memeriksa adanya pengaruh tetap atau random pada individu atau periode waktu. Perbedaan mendasar antara pengaruh tetap dan pengaruh random terletak pada peran variabel dummy. Estimasi parameter pada variabel dummy adalah bagian dari intersep pada model efek tetap dan komponen error pada model efek random. Koefisien kemiringan/slope tetap sama baik pada model efek tetap maupun pada model efek random. Bentuk fungsi satu arah (one way) dari model tetap dan model random adalah sebagai berikut:

$$
\begin{aligned}
& \text { Fixed effect model: } y_{i t}=\left(\alpha+u_{i}\right)+X_{i t}^{\prime} \beta+v_{i t} \\
& \text { Random effect model: } y_{i t}=\alpha+X_{i t}^{\prime} \beta+\left(u_{i}+v_{i t}\right)
\end{aligned}
$$

dimana $u_{i}$ adalah pengaruh tetap atau random untuk individu atau periode waktu yang tidak dimasukkan ke dalam persamaan regresi.

Model efek tetap (fixed effect model) memeriksa perbedaan individu pada intersep, mengasumsikan kemiringannya yang sama dan varians konstan 
antar individu. Ketika efek tertentu dari individu adalah time invariant (tidak dipengaruhi oleh waktu) dan dipertimbangkan sebagai bagian dari intersep, $u_{i}$ boleh berkorelasi dengan regresor lainnya.

Model efek tetap ini diestimasi dengan regresi least squares dummy variable (LSDV) dan metode estimasi within effect. Model efek random mengasumsikan bahwa efek individu tidak berkorelasi dengan regresor manapun maka estimasi varians error dispesifikan untuk kelompok atau waktu. Oleh karena itu, $u_{i}$ adalah komponen komposit error. Inilah mengapa model efek random disebut sebagai Error Component Model. Baik intercept maupun slope sama antar individu. Perbedaan diantara individu atau periode waktu terletak dalan error spesifik individu bukan pada intersepnya.

Model efek random diestimasi dengan metode GLS jika struktur kovariansnya diketahui. (Baltagi and Cheng, 1994). Model efek random mengurangi jumlah parameter yang diestimasi tapi akan menghasilkan estimasi yang tidak konsisten jika efek spesifik individu berkorelasi dengan regresor $[8,9]$.

Efek tetap diuji dengan Uji F, sedangkan efek random diperiksa oleh uji Lagrange multiplier (LM) [6]. Jika hipotesis nol tidak ditolak pada uji ini regresi OLS Pooled disarankan untuk digunakan. Uji spesifikasi Hausman (Hausman, 1978) membandingkan model efek tetap dan model efek acak. Jika hipotesis nol yang menyatakan tidak ada korelasi antara efek individu dengan regresor tidak di tolak, model efek random disarankan daripada efek tetap. Perbandingan model efek tetap dan efek random disajikan pada tabel di bawah ini:

Tabel 1. Model efek tetap dan efek random

\begin{tabular}{lll}
\hline & Fixed Effect Model & Random Effect Model \\
\hline Functional form & $y_{i t}=\left(\alpha+u_{i}\right)+X_{i t}^{\prime} \beta+v_{i t}$ & $y_{i t}=\alpha+X_{i t}^{\prime} \beta+\left(u_{i}+v_{i t}\right)$ \\
Assumption & - & Individual effects are not correlated with regressors \\
Intercepts & Varying across group and/or time & Constant \\
Error variances & Constant & Randomly distributed across group and/or time \\
Slopes & Constant & Constant \\
Estimation & LSDV, within effect estimation & GLS, FGLS (EGLS) \\
Hypothesis test & F test & Breusch-Pagan LM test \\
\hline
\end{tabular}

\section{Estimasi Model Pada Data Panel}

\section{A. Model Fixed Effect}

LSDV dengan dummy variabel banyak digunakan karena relatif mudah dan menginterpretasikan hasilnya. $y_{i t}=\beta_{0}+b_{1} x_{i t}+\mathrm{Y}_{2} \mathrm{D} 2_{\mathrm{i}}+\mathrm{Y}_{3} \mathrm{D} 3_{\mathrm{i}}$ $+\ldots+\mathrm{Y}_{2} \mathrm{DN}_{\mathrm{i}}+u_{\mathrm{it}}$. Akan tetapi LSDV akan menjadi masalah jika terlalu banyak individu atau kelompok yang ada pada data panel karena akan menggunakan variabel dummy yang sangat banyak pula yang mengakibatkan banyaknya parameter yang harus diestimasi. Di bawah keadaan ini, LSDV menjadi tidak berguna. Strategi lainnya dengan menggunakan estimasi within transformation. 
Berbeda dengan LSDV, Estimasi "within" tidak membutuhkan variabel dummy tetapi menggunakan deviasi dari rata-rata kelompok (periode). Estimasi "within" menggunakan variasi dalam setiap individu daripada menggunakan sejumlah besar variabel dummy.

Metode estimasi "within" adalah sebagai berikut:

$$
\left(y_{i t}-\bar{y}_{i .}\right)=\left(x_{i t}-\bar{x}_{i .}\right)^{\prime} \beta+\left(\left(\varepsilon_{i t}-\varepsilon_{i .}\right)\right.
$$

dengan $\bar{y}_{i}$ adalah rata-rata variabel dependen dari individu i, $\boldsymbol{x}_{\boldsymbol{i}}$ adalah ratarata dari variabel independen untuk kelompok i dan $\boldsymbol{\varepsilon}_{i}$ adalah rata-rata error untuk kelompok i.

$$
s e_{k}^{*}=s e_{k} \sqrt{\frac{d f_{\text {error }}^{\text {with }}}{d f_{\text {error }}^{L S D V}}}=s e_{k} \sqrt{\frac{n T-k}{n T-n-k}}
$$

\section{B. Model Random Effect}

Model efek random ditaksir oleh GLS jika struktur kovarians diketahui dan dengan FGLS atau EGLS jika struktur kovarians error komposit tidak diketahui. Dalam EGLS pertama kali kita harus menaksir $\theta$ menggunakan $\sigma_{\mathrm{u}}{ }^{2}$ dan $\sigma_{\mathrm{v}}^{2}$. $\sigma_{\mathrm{u}}{ }^{2}$ diperoleh dari regresi rata-rata kelompok dan $\sigma_{\mathrm{v}}^{2}$ diperoleh dari SSE estimasi within.

$$
\begin{aligned}
& \hat{\theta}=1-\sqrt{\frac{\hat{\sigma}_{v}^{2}}{T \hat{\sigma}_{u}^{2}+\hat{\sigma}_{v}^{2}}}=1-\sqrt{\frac{\hat{\sigma}_{v}^{2}}{T \hat{\sigma}_{\text {between }}^{2}}}, \\
& \text { where } \hat{\sigma}_{u}^{2}=\hat{\sigma}_{\text {tetween }}^{2}-\frac{\hat{\sigma}_{v}^{2}}{T}, \text { where } \hat{\sigma}_{\text {between }}^{2}=\frac{S S E_{\text {between }}}{n-k-1}, \\
& \hat{\sigma}_{v}^{2}=\frac{S S E_{\text {within }}}{n T-n-k}=\frac{e^{\prime} e_{\text {within }}}{n T-n-k}=\frac{\sum_{i=1}^{n} \sum_{t=1}^{T}\left(v_{\text {it }}-\bar{v}_{i \bullet}\right)^{2}}{n T-n-k},
\end{aligned}
$$

Transformasikan variabel dependen dan independen menjadi

$$
\begin{aligned}
y_{i t}^{*} & =y_{i t}-\hat{\theta} \bar{y}_{i \bullet} \\
\dot{x}_{i t}^{*} & =x_{i t}-\hat{\theta} \bar{x}_{i \bullet} \text { for all } x_{k} \\
\dot{\alpha}^{*} & =1-\hat{\theta}
\end{aligned}
$$

Persamaan regresi yang baru hasil transformasi inilah yang merupakan model "between" $y_{i t} *=a^{*}+\beta x_{i t} *+\varepsilon_{i t} *$

\section{Testing Fixed and Random Effects}

Efek tetap diuji dengan uji $\mathrm{F}$ sedangkan efek random dengan uji LM. Kesamaan estimator efek tetap dan efek random aka diuji melalui uji Hausman.

\section{A. Uji F untuk Fixed Effects}

Berdasarkan model efek tetap $y_{i t}=\alpha+\mu_{i}+X^{\prime} \beta+\varepsilon_{i t}$, Hipotesis nol untuk uji $\mathrm{F}$ ini adalah $H_{0}: \mu_{1}=\ldots=\mu_{n-1}=0$, hipotesis alternatifnya adalah paling sedikit satu parameter dummy tidak nol. Hipotesis ini diuji dengan uji $\mathrm{F}$ berikut ini 


$$
F(n-1, n T-n-k)=\frac{\left(e^{\prime} e_{\text {pooled }}-e^{\prime} e_{L S D V}\right) /(n-1)}{\left(e^{\prime} e_{L S D V}\right) /(n T-n-k)}=\frac{\left(R_{L S D V}^{2}-R_{\text {pooled }}^{2}\right) /(n-1)}{\left(1-R_{L S D V}^{2}\right) /(n T-n-k)}
$$

Jika hipotesis nol ditolak, dapat disimpulkan bahwa ada efek tetap yang signifikan sehingga model efek random lebih baik daripada OLS Pooled.

\section{B. Uji LM Breusch-Pagan untuk Random Effects}

Breusch and Pagan's (1980) Lagrange multiplier (LM) menguji komponen varians dari individu tertentu adalah nol $\mathrm{H}_{0}=\sigma_{u}^{2}$. Statistik LM mengikuti distribusi chi kuadrat dengan derajat bebas 1 .

$$
L M_{u}=\frac{n T}{2(T-1)}\left[\frac{T^{2} \bar{e}^{\prime} \bar{e}}{e^{\prime} e}-1\right]^{2} \sim \chi^{2}(1)
$$

Baltagi menyatakan statistik LM dengan cara yang lain

$$
L M_{u}=\frac{n T}{2(T-1)}\left[\frac{\sum\left(\sum e_{i t}\right)^{2}}{\sum \sum e_{i t}^{2}}-1\right]^{2}=\frac{n T}{2(T-1)}\left[\frac{\sum\left(T \bar{e}_{i \bullet}\right)^{2}}{\sum \sum e_{i t}^{2}}-1\right]^{2} \sim \chi^{2}(1)
$$

Jika hipotesis nol ditolak, dapat disimpulkan bahwa terdapat efek random yang signifikan pada data panel dan model efek random dapat mengatasi heterogenitas lebih baik dari pada OLS Pooled.

\section{Uji Hausman untuk membandingkan Efek Tetap dan Efek Random}

Bagaimana mengetahui efek mana yang lebih relevan dan signifikan pada data panel dapat diketahui dengan uji Hausman. Uji ini membandingkan model efek random dan model efek random. Hipotesis nol menyatakan bahwa efek individu tidak berkorelasi dengan regresor pada model. Jika hipotesis nol tidak dilanggar, LSDV dan GLS konsisten.

$$
\begin{aligned}
& L M=\left(b_{L S D V}-b_{\text {random }}\right) \hat{W}^{-1}\left(b_{L S D V}-b_{\text {random }}\right) \sim \chi^{2}(k), \\
& \text { where } \hat{W}=\operatorname{Var}\left[b_{L S D V}-b_{\text {random }}\right]=\operatorname{Var}\left(b_{L S D V}\right)-\operatorname{Var}\left(b_{\text {random }}\right)
\end{aligned}
$$

Jika hipotesis nol ditolak artinya ada korelasi antara efek individu dengan paling sedikit satu regresor, maka model efek random bermasalah atau model efek tetap lebih baik digunakan.

\section{Uji Chow untuk Poolability}

Poolabilitas terjadi jika koefisien kemiringan adalah sama untuk antar waktu dan kelompok [1]. Bentuk hipotesis untuk tes Chow ini adalah

$$
H_{0}: B_{i k}=B_{k}
$$

Statistik uji yang digunakan adalah

$$
F[(n-1)(k+1), n(T-k-1)]=\frac{\left(e^{\prime} e-\sum e_{i} e_{i}\right) /(n-1)(k+1)}{\sum e_{i} e_{i} / n(T-k-1)}
$$

Jika Ho ditolak, data panel tidak poolable (tidak dapat digabungkan), artinya 
setiap individu memiliki koefisien regresi yang berbeda untuk semua regresor.

\section{Hasil dan Pembahasan}

Data sampel yang digunakan mengenai Tingkat Kemiskinan pada 26 Kabupaten/Kota di Jawa Barat selama 3 tahun yaitu tahun 2009-2011. Model sampel meregresikan Tingkat kemiskinan sebagai variabel dependen dengan PDRB, PG dan IPM sebagai variabel independen.

Dalam sampel data panel dengan 26 kabupaten/kota dan 3 periode waktu, skema dasar nya adalah Kemiskinan ditentukan oleh PDRB, Pengangguran (PG) dan IPM

OLS: $\mathrm{KM}_{i}=B_{0}+B_{1} P D R B_{i}+B_{2} P G_{i}+B_{3} I P M_{i}+\varepsilon_{i}$

Hasil pengolahan analisis regresi dengan OLS disajikan pada tabel di bawah ini.

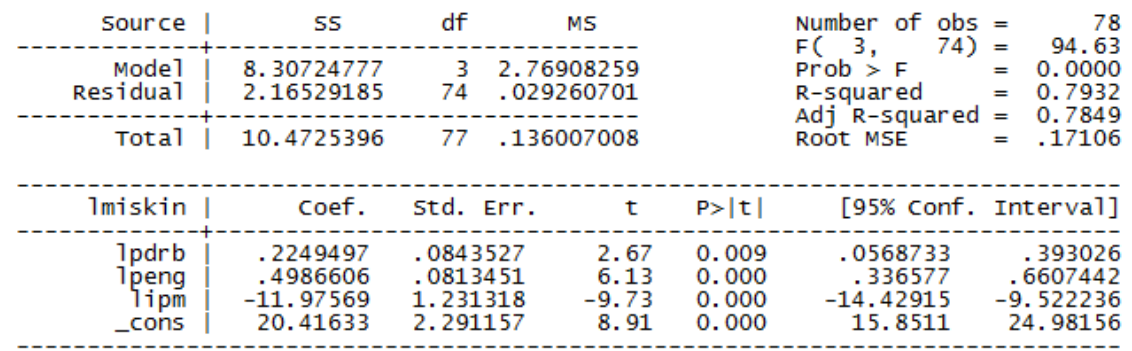

Model OLS ini fit dengan data pada tingkat signifikansi $5 \% . \mathrm{R}^{2}=$ 0.7932 artinya bahwa $79 \%$ total variasi pada kemiskinan ini dapat dijelaskan oleh model regresi berikut ini. $\mathrm{KM}=20.4163+.2249 *$ pdrb +.4986 *peng $-11.9757 *$ ipm. Artinya :

1. Dengan menjaga variabel lain tetap konstan, setiap kenaikan PDRB sebesar 1 satuan, kemiskinan akan meningkat sebesar 0.2249

2. Dengan menjaga variabel lain tetap konstan, setiap kenaikan PG sebesar 1 satuan, kemiskinan akan meningkat sebesar 0.4986

3. Dengan menjaga variabel lain tetap konstan, setiap kenaikan IPM sebesar 1 satuan, kemiskinan akan menurun sebesar 11.9757

OLS Pooled adalah regresi linier gabungan tanpa efek tetap atau efek random. Dalam OLS Pooled ini intersep dan slope diasumsikan konstan baik untuk individu maupun periode waktu. Hasil OLS menghasilkan bahwa model ini fit dengan data, persoalannya adalah apakah setiap tahun untuk setiap kabupaten/kota memiliki tingkat kemiskinan yang berbeda? Apakah faktor error antar kota dan atau antar tahun bervariasi? Pooled OLS memperlakukan semua kabupaten dan kota untuk setiap tahun memiliki model yang sama. 


\section{Model Fixed Effect}

Untuk memeriksa efek tetap kelompok dilakukan analisis regresi dengan menggunakan variabel boneka yang diatur untuk membedakan kota. Banyaknya variabel boneka adalah N-1 sehingga terdapat 25 buah variabel boneka dalam contoh ini dan membentuk model LSDV sebagai berikut:

LSDV:

$\mathrm{KM}_{i}=B_{0}+B_{1} p d r b_{i}+B_{2} \mathrm{pg}_{i}+B_{3} i p m_{i}+u_{1} g_{1}+u_{2} g_{2}+\ldots+u_{25} g_{25}+\varepsilon_{i}$

dengan $\mathrm{g}_{\mathrm{i}}=1$ untuk kota $\mathrm{i}$ dan $\mathrm{g}_{\mathrm{i}}=0$ untuk kota lainnya, selanjutnya terhadap variabel boneka tersebut diregresikan dengan KM. Hasil dari LSDV tersebut adalah sebagai berikut:

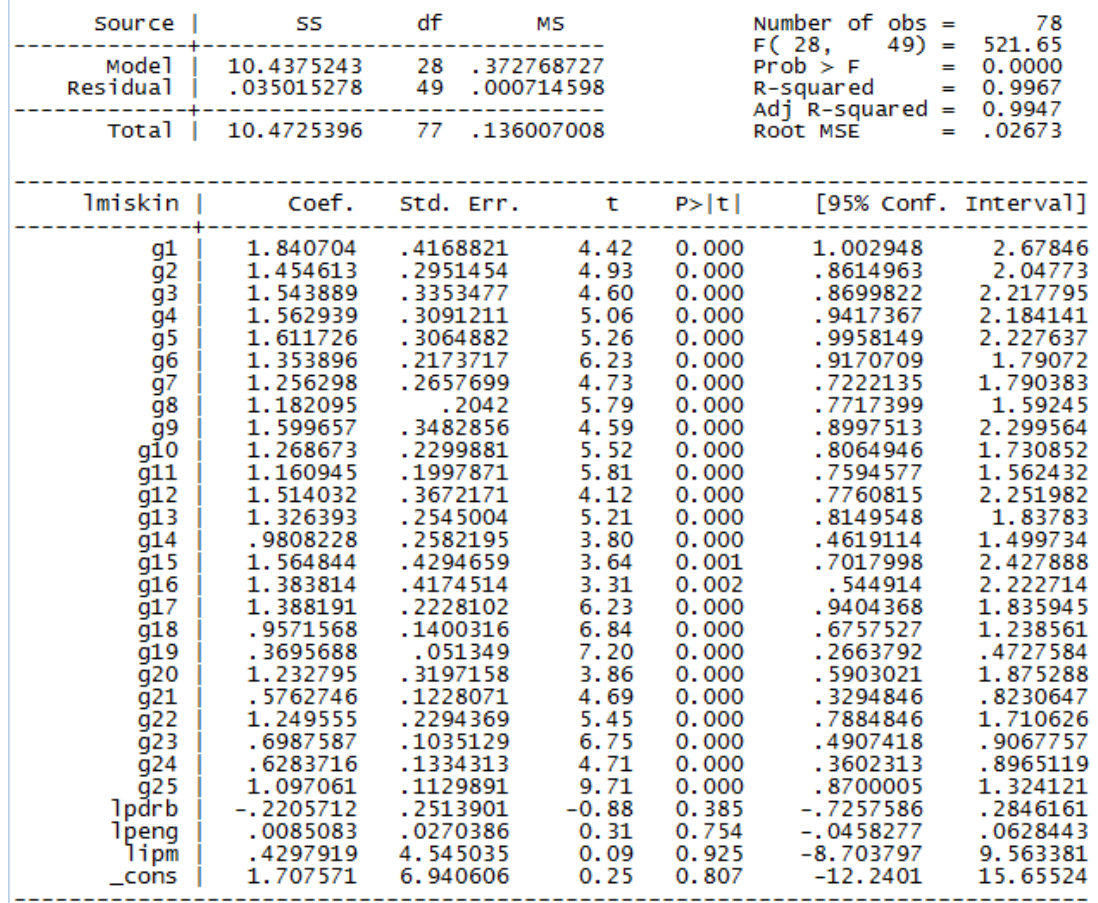

LSDV ini menghasilkan kecocokan model dengan data yang lebih baik dari pada regresi Pooled. Hal ini terlihat dari nilai statistik F yang meningkat dari 94.63 menjadi 521.65 ( $\mathrm{p}<.0000)$; SSE (sum of squares due to error or residual) menurun dari 2.165 menjadi .035; dan $\mathrm{R}^{2}$ meningkat dari dari 0.7932 menjadi 0.9967. Estimasi koefisien regresi untuk variabel independen sedikit berbeda akan tetapi tidak merubah signifikasinya.

Dengan model LSDV ini setiap kota/kabupaten akan memiliki intersep yang berbeda dengan slope yang tetap sama. Ini menunjukkan adanya pengaruh tetap (fixed effect). Dengan LSDV semua ukuran kecocokan model menjadi lebih baik dibandingkan dengan regresi Pooled akan tetapi untuk menyakinkan perlu diuji secara formal untuk memeriksa adanya efek tetap tersebut. 


\section{Testing a Fixed Effect (F-test)}

Hipotesis nol untuk Uji F ini adalah bahwa semua parameter dummy adalah nol.

$$
H_{0}: \mu_{1}=\ldots=\mu_{n-1}=0
$$

Uji menghitung statistik uji F, menggunakan SSE dari regresi Pooled (2.165) dan SSE dari LSDV (.0350) yang hasilnya adalah sebagai berikut:

$$
\mathrm{F}=\frac{(2.165-.0350) /(26-1)}{.0350 /(78-26-3)}=119,28
$$

Nilai F hitung sebesar 119,28 cukup besar untuk menolak hipotesis nol yang artinya terdapat cukup bukti bahwa adanya efek tetap pada model.

\section{Model Random Effect}

Model efek random memeriksa pengaruh variasi error kelompok atau waktu. Untuk mendapatkan nilai $\theta$ untuk FLGS, lakukan estimasi "between" terlebih dahulu.

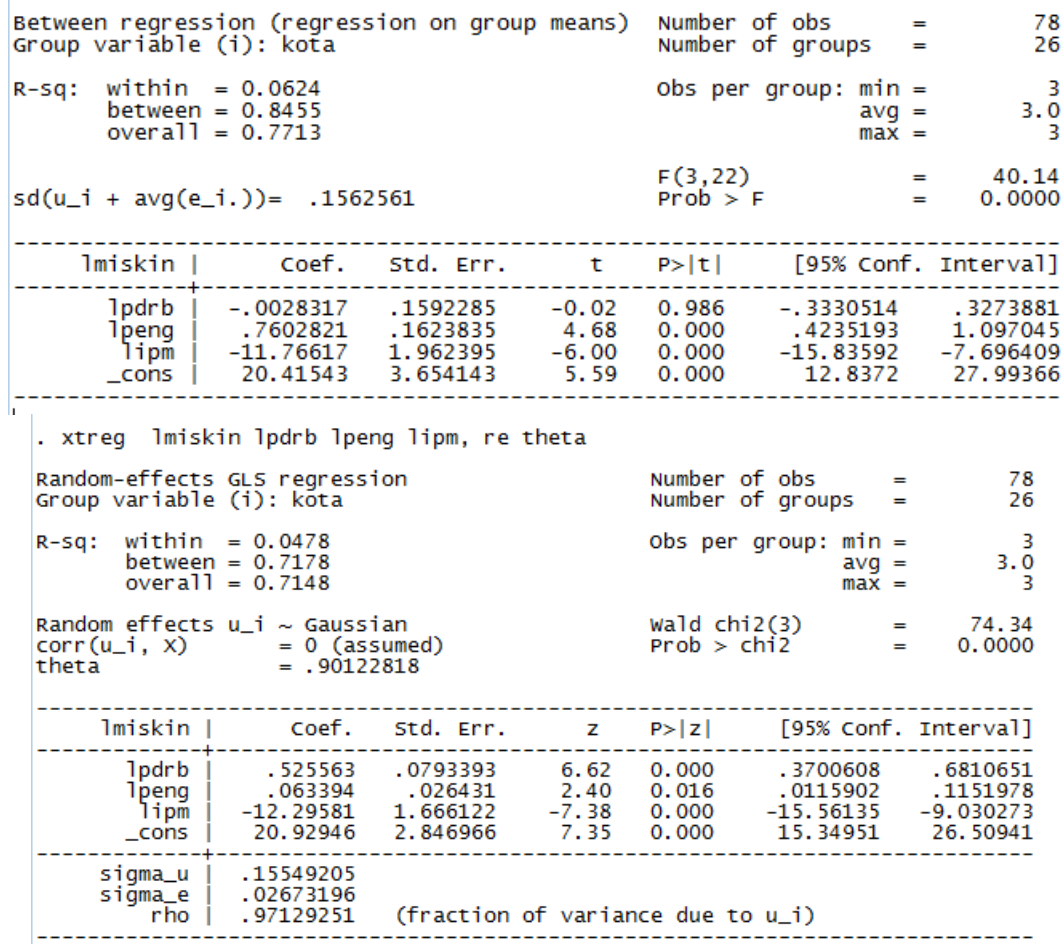

Rasio yang besar berarti error spesifik milik individu menjelaskan proporsi yang besar dari varians error komposit . Pada model ini error tertentu individu dapat menjelaskan 97 persen dari seluruh varians komposit error. Nilai rho ini dapat diinterpretasikan sebagai kecocokan model efek random. 


\section{Testing a Random Effect: LM test}

Uji Breusch-Pagan Lagrange multiplier (LM) memeriksa apakah ada efek random dalam model. Hipotesis nolnya adalah bahwa Varians komponen error tidak sama dengan nol. Breusch and Pagan Lagrangian multiplier test untuk random effects:

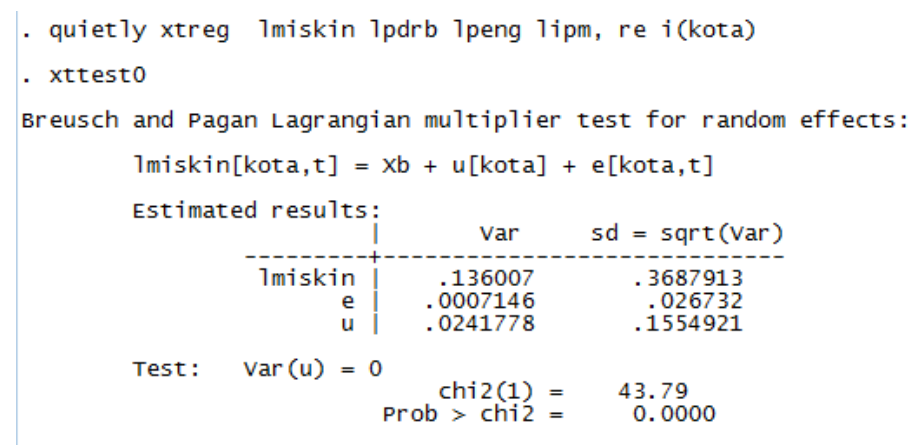

Dengan nilai chi-squared sebesar 43.79, hipotesis nol ditolak yang artinya model efek random lebih baik dari pada model OLS Pooled.

\section{Hausman Test}

Jika ditemukan efek tetap dan efek random yang signifikan, lakukan tes spesifikasi Hausman untuk mengetahui manakah efek yang lebih signifikan dan model yang lebih baik.

\begin{tabular}{|l} 
- hausman random_group fixed_group \\
$\begin{array}{r}\text { (b) } \\
\text { random_group fixed_group }\end{array}$ Difference
\end{tabular}

Dari nilai chi square sebesar -10.70 pada hasil ini tidak cukup membuktikan bahwa hipotesis nol diterima karena nilai chi tidak boleh negatif. Hal ini disebabkan adanya asumsi yang tidak dipenuhi pada saat melakukan hausman test.

\section{Chow Test for Poolability}

Uji Poolabilitas Chow memeriksa apakah data panel dapat digabungkan sehingga slope dari semua variabel independen sama untuk semua individu 
atau periode waktu. (Bantagi, 2001: 51-55). Bentuk hipotesis untuk tes Chow ini adalah

$$
H_{0}: B_{i k}=B_{k}
$$

Jika Ho ditolak, data panel tidak poolable (tidak dapat digabungkan), artinya setiap individu memiliki koefisien regresi yang berbeda untuk semua regresor maka pengaruh fixed dan atau random menjadi tidak ada. Untuk melakukan uji ini, lakukan OLS untuk setiap kelompok (atau waktu). SSE dari OLS Pooled $\left(e^{\prime} e\right)$, is 2.1652 dan jumlah dari SSE masing masing kelompok sigma $e_{i}{ }^{\prime} e_{i}$, is $1.77737=.80066+.54541+.4120$. Statistik $\mathrm{F}$ menghasilkan nilai 5.499 yang menolak hipotesis nol mengenai poolabilitas $(\mathrm{p}<$.0000). Dapat disimpulkan bahwa data panel tidak dapat digabungkan. Baik model random dan model random mungkin akan menyesatkan dan perlu dicoba model koefisien random atau model regresi bertingkat (hierarchical linear regression model).

\section{Simpulan dan Saran}

1. Dengan melibatkan seluruh kabupaten dan kota di Jawa Barat dalam estimasi pemodelan menunjukkan bahwa secara parsial PDRB mempunyai pengaruh positif yang signifikan terhadap kemiskinan. Artinya semakin tinggi PDRB di suatu kabupaten/kota akan meningkatkan kemiskinan.

2. Dengan melibatkan seluruh kabupaten dan kota di Jawa Barat dalam estimasi pemodelan menunjukkan bahwa secara parsial Pengangguran mempunyai pengaruh positif yang signifikan terhadap kemiskinan. Artinya semakin tinggi pengangguran di suatu kabupaten/kota akan meningkatkan kemiskinan.

3. Dengan melibatkan seluruh kabupaten dan kota di Jawa Barat dalam estimasi pemodelan menunjukkan bahwa secara parsial IPM mempunyai pengaruh negatif yang signifikan terhadap kemiskinan. Artinya semakin tinggi IPM di suatu kabupaten/kota akan menurunkan kemiskinan.

4. Dengan menggunakan data panel terhadap 26 kabupaten dan kota di Jawa Barat pada tahun 2009 sampai 2011 yang dianalisis untuk mencari efek individu atau waktu menggunakan model efek tetap dan model efek random menunjukkan bahwa kedua Uji F (fixed effect test) dan Uji LM (random effect test) menghasilkan $\mathrm{H}_{0}$ ditolak yang berarti bahwa model harus diuji dengan Uji Hausman untuk memastikan bahwa model terbaik. Hasil Uji Hausman menyatakan bahwa $\mathrm{H}_{0}$ diterima yang artinya model yang lebih baik adalah model efek tetap. Model efek tetap akan menunjukkan besarnya masing-masing variabel PDRB, Pengangguran dan IPM dalam mempengaruhi Kemiskinandi Jawa Barat akan berbeda-beda untuk setiap kabupaten/kota tahun 2009-2011. Dengan menggunakan model LSDV besarnya pengaruh simultan PDRB, Pengangguran, IPM 
secara bersama-sama terhadap Kemiskinan adalah 99,7 persen.

\section{Saran}

1. PDRB berdasarkan hasil penelitian berpengaruh positif dan signifikan terhadap kemiskinan sedangkan secara teori semestinya pengaruh ini bersifat negatif, hal ini mungkin disebabkan bahwa kemungkinan PDRB di Jawa Barat tidak menyentuh secara langsung dalam mengentaskan masyarakat miskin.

2. Pengangguran berdasarkan hasil penelitian berpengaruh positif dan signifikan terhadap kemiskinan, dengan hasil tersebut diharapkan Pemerintah Propinsi Jawa Barat dapat mencari pendekatan yang terbaik dalam menekan angka pengangguran sehingga dampaknya dapat menurunkan tingkat kemiskinan misalkan dengan menggerakan sektor informal dan membuka kesempatan yang luas dalam kewirausahaan.

3. IPM berdasarkan hasil penelitian berpengaruh positif dan signifikan terhadap kemiskinan, dengan hasil tersebut diharapkan Pemerintah Propinsi Jawa Barat untuk bisa lebih baik dalam mengentaskan kemiskinan dengan membuat program-program bagi masyarakat yang bisa meningkatkan IPM.

\section{Daftar Pustaka}

1. Baltagi, Badi H. 2001. Econometric Analysis of Panel Data. Wiley, John \& Sons.

2. Baltagi, Badi H., and Young-Jae Chang. 1994. Incomplete Panels: A Comparative Study of Alternative Estimators for the Unbalanced Oneway Error Component Regression Model. Journal of Econometrics, 62(2): 67-89.

3. BPS Provinsi Jawa Barat, Jawa Barat dalam Angka 2010

4. $\quad$ BPS Provinsi Jawa Barat, Jawa Barat dalam Angka 2011

5. $\quad$ BPS Provinsi Jawa Barat, Jawa Barat dalam Angka 2012

6. Breusch, T. S., and A. R. Pagan. 1980. The Lagrange Multiplier Test and its Applications to Model Specification in Econometrics. Review of Economic Studies, 47(1): 239-253. Cameron, A. Colin, and Pravin K. Trivedi. 2009.

Microeconometrics: Methods and Applications. New York: Cambridge University Press.

7. Cameron, A. Colin, and Pravin K. Trivedi. 2009. Microeconometrics Using Stata. TX: StataPress.

8. Greene, William H. 2007. LIMDEP Version 9.0 Econometric Modeling Guide 1. Plainview, New York: Econometric Software.

9. Greene, William H. 2011. Econometric Analysis, 6th ed. Upper Saddle River, NJ: Prentice Hall.

10. Gujarati Damodar. 2004. Basic Econometrics Fourth Edition: United States Military Academy, New York. 
11. Hsiao, Cheng. 2003. Analisis of Panel Data. Cambridge: Cambridge University Press

12. Human Development Report. 1995. Published for the United Nations Development Programme (UNDP). New York. Oxford. Oxford University Press 1995

13. Kennedy, Peter. 2008. A Guide to Econometrics, 6th ed. Malden, MA: Blackwell Publishing

14. Mudrajad Kuncoro. 1997. Ekonomi Pembangunan Teori, Masalah, dan Kebijakan. Yogyakarta: UPP AMP YKPN.

15. Mudrajad Kuncoro. 2001. Metode Kuantitatif: Teori dan Aplikasi untuk Bisnis dan Ekonomi. Edisi kesatu, UPP AMP YKPN, Yogyakarta.

16. Pantjar Simatupang dan Saktyanu K. Dermoredjo. 2003. Produksi Domestik Bruto, Harga dan Kemiskinan.

17. Sadono Sukirno. 2000. Makro Ekonomi Modern: Perkembangan Pemikiran dari Klasik sampai Keynesian. Lembaga Penerbit FE-UI. Jakarta.

18. Wooldridge, Jeffrey M. 2010. Econometric Analysis of Cross section and Panel Data. $2^{\text {nd }}$ ed. Cambridge, MA: MIT Press. 